Dr Janko Kubinjec advokat u Bačkom Petrovcu

\title{
USPOSTAVLJANJE STVARI*
}

SAŽETAK: Pravni institut lica se konstituiše a pravni institut stvari se uspostavlja. Pravni institut stvari je metafizička kategorija, koju treba jasno razlikovati od pozitivno-pravnog određenja stvari kao empirijskog fenomena, kao i od prirodne stvari kao takođe empirijskog fenomena. Pravni institut stvari je duhovni fenomen koji pripada sferi objektivnog duha. Stvar je temelj celokupnog građanskog prava. Pogrešno stanovište da građansko pravo počinje sa vlasništvom a vlasništvo sa posedom, zasnovano je na tzv. naturalističkoj grešci. U svojini se licu stvar javlja najpre kao sloboda, dok je hipoteka pre svega granica koja se suprotstavlja vlasniku. Na svojevrsnom prelivanju slobode iz lica u stvar zasniva se erga omnes dejstvo stvarnih prava. Izvan određenja prava kao slobode nije moguće jasno i suštinsko razlikovanje lica i stvari a bez tog razlikovanja se i lica mogu odrediti kao res cogitans. U stvarnom pravu se suština manifestuje neposredno kroz stvar a sa prelaskom u obligaciono pravo ta se suština pojavljuje kroz odnos između ljudi. U obligacionom pravu se stvar potiskuje sve dok se ne dospe do imovine, odnosno dok se vlasništvo ne svede na potraživanje. Ako pored toga dođe i do neposredno prirodne negacije stvari, srećemo se sa pravnim institutom štete. $U$ autentičnom pravu je sukcesija uvek institut stvari a samo u neautentičnom to može biti i institut lica.

Ključne reči: Stvar, metafizički fenomen, empirijski fenomen, duh, naturalistička greška, svojina, hipoteka, imovina, potraživanje, šteta, sukcesija

Osnovni instituti prava su lice i stvar. ${ }^{1}$ Lice se kao pravni institut konstituiše ${ }^{2}$ a stvar se kao pravni institut uspostavlja. Temelji ovakve raz-

* Rad primljen: 04. IX 2006. godine.

1 „Omne autem ius quo utimur, vel ad personas pertinet vel ad res vel ad actiones." (Sve pravo kojim se služimo odnosi se ili na lica ili na stvari ili na tužbe." (Gaj: Institucije, 
like nisu svečano-pesničke, nego strogo filozofske prirode. Lice naime produkuje sâmo sebe u aktu duhovne kreacije čoveka - kao subjekta koji sebe konstituiše u lice. Stvar nasuprot tome sama po sebi nema nikakvu zaslugu u aktu svog apstraktnog određenja - njeno apstraktno određenje vrši isključivo čovek, te je on na taj način uspostavlja kao stvar - kao stvar u pravnom smislu, kao apstraktnu stvar.

Institut stvari je apriorna pravna kategorija. Ne treba međutim izgubiti iz vida da su svi pravni instituti apriorne kategorije. ${ }^{3}$ To znači da stvar kao pravni institut, kao i svi pravni instituti uopšte, po svom ontološkom poreklu nije empirijske prirode. Reč je naime o metafizičkim kategorijama čija egzistencija kao instituta ne zavisi od toga da li one i u kakvom određenju postoje faktički u empirijskom svetu. To ujedno znači da naše saznanje o njima ne potiče iz iskustva i upravo u tome se i sastoji njihova apriorna priroda.

Apriornost instituta stvari nije dakle u svetu pravnih instituta ništa specifično. Možda je razlika samo u tome što je pogodnije da se na tu apriornost ukaže upravo kada je reč o pravnom institutu stvari. Kada je reč o stvari, više je nego jasno da se najpre formira institut stvari izvan svake empirijske egzistencije pojedinačne stvari - a empirijska egzistencija uvek podrazumeva ono pojedinačno jer nešto kao egzistencija onoga što je opšte jeste protivrečnost samo po sebi. Institut stvari se najpre formira u sferi duhovnosti kao ono apriorno i tek naknadno stupa u empiriju u aktu vezivanja za pojedinačnu empirijski postojeću stvar.

Objektivna duhovnost je po svojoj prirodi indiferentna prema vremenu. Kada je reč o pravnom fenomenu, možemo reći da materijalno pravo u potpunosti karakteriše ova indiferentnost prema temporalnosti (dok je kod procesnog prava situacija specifična ${ }^{4}$ ). Pravni institut stvari kao tvorevina objektivnog duha u stalnoj je suprotstavljenosti vremenu - u pravnom institutu stvari duhovnost pokušava da dotakne nadvremenost, duhovnost je ovde okrenuta večnostị. Ali, ono što je ovde od suštinskog značaja je to da ta okrenutost večnosti ne proizvodi nikakvu ,unutrašnju napetost", da je pravni institut stvari i prema ovoj težnji ka nadvremenosti sasvim indiferentan. Kratko rečeno, nije težnja ka večnosti, nego je indiferentnost prema temporalnosti ono što je ovde od suštinskog značaja.

Pravni institut stvari u ovom našem svetu ima na taj način svojevrsnu superiornu distancu prema onome što se odvija u vremenu. Pojedi-

I. 8, Nolit, Beograd, 1982, str. 34, odnosno 35). O razlici između institucione i pandektne sistematizacije videti i: Nikolić, D.: Uvod u sistem građanskog prava, Pravni fakultet Novi Sad, 2005, str. 52-54.

2 O problemu konstituisanja lica pisao sam u članku Konstituisanje lica, koji je objavljen u Glasniku $A K V$, br. 11/2004, Novi Sad, str. 437-454.

3 Drukčije kod Radbruha: „Svojina je apriorna pravna kategorija, dok lična svojina ili zajednička svojina to nisu." (Radbruh, G.: Filozofija prava, Nolit, Beograd, str. 172). Ako se filozofija prava zasnuje kao filozofija ontoloških zakonitosti pravnog fenomena - kao što ovde pokušavam da učinim - onda su nužno svi pravni instituti bez izuzetka apriornog karaktera.

4 O temporalnosti u procesnom pravu uporediti moj članak Osnovne naznake filozofije procesnog prava, Pravni život, Beograd, br. 12/2003, str. 878-881. 
načne empirijske stvari nastaju i nestaju, stupaju u egzistenciju i gube se u ništavilu. Temporalnost je unutrašnja priroda empirijskog sveta. U empirijskom svetu stvari nastaju i stupaju u odnos sa institutom stvari kao duhovnim fenomenom. Empirijska stvar i pravni institut stvari su u međusobnom ravnodušnom odnosu - za suštinu kako jedne, tako i druge kategorije, sasvim je irelevatno da li će u taj odnos zaista da stupi. Empirijska stvar ništa ne dobija u svojim empirijskim karakteristikama nakon stupanja u odnos sa pravnim institutom stvari, kao što, s druge strane, ni pravni institut niti šta dobija, niti šta gubi stupanjem u odnos sa pojedinačnim empirijskim stvarima.

$\mathrm{Na}$ ovom mestu je neophodno ukazati na jedno precizno razlikovanje. Mi ovde govorimo o pravnom institutu stvari za koji je već rečeno da nije empirijske prirode, da je dakle čisto metafizička kategorija. Ono na šta ovde želim da ukažem jeste sledeće: ovaj pravni institut stvari treba jasno razlikovati od stvari kao instituta pozitivnog prava. Stvar kao institut pozitivnog prava jeste empirijska kategorija, kao što je celokupno pozitivno pravo bez ostatka empirijski fenomen. Kada govorimo o pravnom institutu stvari kao takvom, tada se još međutim ne nalazimo na području pozitivnog prava, na području empirije, nego na području onog pred-empirijskog, onog metafizičkog. I upravo nam to pruža mogućnost apriornog saznanja pojma pravnog instituta stvari.

Pozitivno pravno određenje stvari mora biti zasnovano na metafizičkom pravnom institutu stvari a to znači na zakonitosti stvari kao instituta. Ako to nije tako, pozitivno pravo nije autentično. Dakle, odnos metafizičkog pravnog instituta stvari i njegovog pozitivno-pravnog određenja ni u najmanjoj meri nije indiferentan. $\mathrm{O}$ indiferentnosti možemo govoriti samo kada se radi o uspostavljanju odnosa prema empirijskim stvarima.

Empirijske pojedinačne stvari nikada ne stupaju u neposredan odnos sa metafizičkim pravnim institutom stvari - neposredni odnos one uspostavljaju samo sa pozitivnim pravom. Ali i taj odnos sa pozitivnim pravom je njima kao empirijskim fenomenima spoljašnja, ravnodušna odredba.

U ovom smislu možemo čak reći da pravni institut stvari, kao metafizički zakon pravnog fenomena, da dakle stvar kao pravni institut nema ničeg zajedničkog sa empirijskom stvari. Ako metafizički pravni institut stvari ne stupi u relevantan odnos ni sa jednom pojedinačnom stvari u empiriji, to njemu i njegovoj suštini ništa ne može da naškodi jer je taj institut indiferentan i prema egzistenciji i prema vremenitosti kao jednoj njenoj odredbi. S druge strane, ako nijedna pojedinačno postojeća, empirijski postojeća pojedinačna stvar u vremenu ne stupi u bilo kakav odnos sa metafizičkim pravnim institutom stvari, to njoj kao empirijskom fenomenu isto tako ništa neće značiti. Odnos ova dva momenta od odlučujućeg je značaja samo za fenomen koji stoji između empirijskih pojedinačnih stvari i metafizičkog pravnog instituta stvari. Taj srednji sloj njihovog povezivanja jeste pozitivno pravo. Za pozitivno pravo je upravo od odlučujućeg značaja da li će ono uspeti da isposreduje povezivanje metafizič- 
ke i empirijske određenosti stvari. Ovo zbog toga što od usklađenosti pozitivnog prava sa metafizičkom sferom zavisi njegova autentičnost, dok s druge strane od stepena u kome se empirijska sfera vezuje na pozitivno pravo - zavisi njegova efikasnost.

Pravno određenje stvari dakle ne tangira njenu empirijsku prirodu i utoliko se može reći da je pravno određenje stvari njeno apstraktno određenje. Odnos empirijske stvari i njenog apstraktnog pravnog određenja je upravo onakav kakav je odnos upotrebne i prometne vrednosti robe u ekonomskom fenomenu. I kao što je upotrebnoj vrednosti robe njena apstraktna prometna vrednost sasvim indiferentna, tako je i empirijskoj pojedinačnoj stvari, kao empirijskoj, sasvim indiferentna njena apstraktna određenost putem pravnog instituta stvari. I kao što je, s druge strane, prometnoj vrednosti robe, kao apstraktnoj određenosti, sasvim irelevantna njena upotrebna vrednost, tako je i pravnom institutu stvari sasvim irelevantan empirijski „sadržaj”, empirijski identitet stvari kao empirijskog fenomena. Jedino je roba ono čega nema bez povezivanja upotrebne i prometne vrednosti, jedino je pozitivno pravo ono čega nema bez povezivanja pravnog instituta stvari i empirijski pojedinačne stvari.

$\mathrm{Na}$ taj način smo uspostavili razlikovanje u tri različite ravni, od kojih jedna ide područjem metafizike a dve područjem empirije. Reč je o određenju instituta stvari u metafizičkoj sferi a u empirijskoj sferi o razlikovanju stvari kao instituta pozitivnog prava i najzad empirijski pojedinačne (,fizikalne”) stvari. Određenjem instituta stvari u metafizičkoj sferi bavi se filozofija prava, dok se određenjem instituta stvari u pozitivnom pravu bave pravna pragmatika i pravna teorija.

Pravno određenje empirijske stvari je njeno apstraktno određenje. Pravna komponenta tog određenja je sazdana od duhovnog supstrata, dok je ,fizikalna” komponenta nosilac te duhovnosti. To znači da je u pogledu slojevanja u pravnom fenomenu situacija analogna onoj koju srećemo u umetničkom fenomenu u tom smislu što u oba ova fenomena možemo jasno razlikovati sloj nosioca duhovnosti i sloj specifične pravne, odnosno umetničke duhovnosti. ${ }^{5}$

Međutim, dok u umetničkom fenomenu sloj specifične umetničke duhovnosti, dakle onaj sloj koji je nošen, prodire u sloj nosioca duhovnosti, dotle u pravnom fenomenu specifična pravna duhovnost samo prianja uz sloj nosioca. Da bih jasno ukazao na ono što ovde želim reći, skrećem pažnju na to da umetnički receptor jedne slike može neposrednim čulno-duhovnim opažanjem te slike dopreti do njenog drugog, umetničkog plana, dok „pravni receptor” opažanjem te iste slike nikada ne može dospeti do odgovora na pitanje čije je ona vlasništvo, dakle do onoga što bismo analogno umetnosti mogli da označimo kao drugi, pozadinski pravni

5 Sloj nosioca duhovnosti u umetnosti je npr. platno i boja u slikarstvu, kamen u vajarstvu ili pisana reč u književnosti, dok je u pravnom fenomenu to gotovo bez izuzetka pisana reč. Sloj specifične duhovnosti, koja je nošena onim prvim slojem, u umetnosti je sama umentička duhovnost, dok su u pravnom fenomenu to instituti prava, kao što su lice i stvar, a takođe i pozitivno pravo, itd. 
plan te slike. To je smisao u kome umetnička duhovnost prodire u sloj svog nosioca, dok pravna duhovnost samo prianja uz njega. Upravo u tome se i sastoji smisao stanovišta da je pravno određenje stvari njeno apstraktno određenje. $\mathrm{U}$ istom smislu je i pravno određenje lica apstraktno, samo što je na primeru stvari situacija uočljivija. Kod lica se ponekad čini da je pravo neko unutrašnje svojstvo lica, njegova takoreći prirodna neposrednost - kod stvari je situacija mnogo očiglednija u svojoj suštini: ovde je očigledno da je pravo ono što je duh, ono što je spoljašnje, ono što samo prianja.

Bitna razlika između stvari i lica sastoji se u tome što se licu pravna apstrakcija konstituiše iznutra, iz samog čoveka kao ljudskog bića koji se određuje u lice, dok stvari apstraktno pravno određenje dolazi izvana tako što čovek, kao ono što je izvan stvari, uspostavlja njeno apstraktno određenje. Zbog toga govorimo o konstituisanju lica s jedne strane i uspostavljanju stvari s druge strane.

I lice i stvar pripadaju sferi objektivnog duha i u aktu kreacije (lica, odnosno stvari) svoje poreklo imaju u sferi subjektivnog duha. Subjektivni duh je mesto kreacije objektivnog duha. Subjektivni duh je čovek kao duhovno biće, kao biće sa duhovnom sposobnošću.

Lice kao institut i stvar kao institut jesu kategorije subjektivnog duha. Drugim rečima, zakonitosti izgradnje instituta lica $i$ instituta stvari počivaju u ljudskom umu kao području u kome je lociran subjektivni duh. Usled ovakve svoje lociranosti, ove zakonitosti nisu manje univerzalne, jednako kao što ni zakonitosti logike ne gube na svojoj univerzalnosti zbog toga što potiču iz sfere subjektivne duhovnosti. Zbog smeštenosti u ljudski um, zakonitosti pravnog fenomena - kao i ni zakonitosti logike - nisu subjektivističke u tom smislu što bi bile proizvoljne. Stvar je u tome što ove zakonitosti ne pripadaju psihičkoj sferi, one nisu elementi volje, nego pripadaju isključivo duhovnoj sferi, iako duhovnosti unutar subjekta i utoliko subjektivnoj duhovnosti. Kada se ovi pravni instituti subjektivnog duha - lice i stvar - objektiviraju u aktu kreacije pozitivnog prava, oni istupaju iz uma, iz subjekta i vezuju se za nosioce duhovnosti izvan uma i to bilo za čoveka kao prirodno biće u njegovoj celini, u njegovom celokupnom integritetu (kada nastaje lice u pravnom smislu) ili pak za stvar kao ono što je izvan čoveka (kada nastaje stvar u pravnom smislu). U oba slučaja ovi instituti iz subjektivnog prelaze u objektivni duh s obzirom da pozitivno pravo u celini svog područja bez ostatka jeste fenomen objektivnog duha, oni se ne razlikuju po prirodi nego samo po nosiocu te duhovnosti koja je pozitivno pravo: nosilac duhovnosti kod lica je čovek kao prirodno biće a nosilac duhovnosti stvari u pravnom smislu je stvar u prirodnom (ne-apstraktnom) smislu. Granica koja je uspostavljena između apstraktno-pravnog određenja s jedne strane i nosioca te duhovnosti s druge strane potpuno je istovetna, oštra i jasna i kod lica i kod stvari. Samo što se zdravom razumu razlika između stvari u prirodnom i apstraktnom smislu javlja kao očigledna, dok se ista ta granica između prirodnosti i apstrakcije kada je reč o licu pojavljuje kao nedovolj- 
no razgovetna, pa se često previđa jasna razlika između čoveka i lica, čoveka kao prirodnog subjekta i lica kao istog tog subjekta ali sada već apstraktno-pravno određenog.

Dakle, razlika između lica i stvari kao pravnih instituta nije u njihovoj strukturi, s obzirom da i jedno i drugo sadrži prirodnu odredbu kao nosioca duhovnosti i apstraktnu odredbu kao specifično pravnu duhovnost. Razlika postoji samo u aktu kreacije te duhovnosti. U aktu kreacije lice se konstituiše, nastaje aktom istog tog subjekta koji prerasta u lice. U aktu kreacije stvar s druge strane ostaje pasivna - nju uspostavlja čovek kao biće izvan nje. To znači da pravnost licu dolazi iznutra a stvari izvana. Usled toga, kao što lice prethodi pravnom poretku, tako poredak prethodi stvari (tj. njenom pravnom uspostavljanju): lice se uspostavlja iz subjekta, stvar iz poretka.

Suštinska strukturalna razlika lica i stvari sastoji se u tome što je nosilac duhovnosti kod lica biće koje se od „ostatka prirode” razlikuje po odredbi svoje duhovnosti. ${ }^{6}$ Čovek kao duhovno biće u-svojoj ontološkoj strukturi sadrži tri sloja: materijalno-prirodni, psihički i duhovni. Po odredbi svoje duhovnosti, čovek se razlikuje od celokupne ostale prirode, uključujući i životinjski svet. Pravnom apstrakcijom ovog subjekta koji je čovek, koji je subjektivna duhovnost, konstituiše se lice. Pravnom apstrakcijom prirode izvan čoveka, koja ne sadrži sloj subjektivne duhovnosti, dakle pravnom apstrakcijom bića koje po svojoj neposrednosti nije duhovno - uspostavlja se stvar. Nosilac duhovnosti kod lica je duhovno biće, dok je nosilac duhovnosti kod stvari biće koje u svojoj ontološkoj strukturi ne sadrži duhovnost. Nije dakle materijalnost, nego duhovnost ono što je princip diferencije lica i stvari. Čovek nije lice po odredbi svoje nematerijalnosti jer i čovek ima materijalno telo koje je obuhvaćeno određenjem lica. Prirodna stvar nije stvar u pravnom smislu po odredbi svoje materijalnosti jer i na nematerijalnim fenomenima se uspostavlja pravno određenje stvari.

Mora se, međutim, naglasiti da se diferencija lica i stvari nalazi isključivo na području subjektivne duhovnosti. Kao što je već navedeno, odredba subjektivnosti se kod subjektivne duhovnosti sastoji u tome što je ona locirana u čoveku kao subjektu, što je ona svojstvo ljudskog uma. Ljudski um kao subjektivna duhovnost je isključivi producent objektivne duhovnosti koja je objektivna po odredbi svoje lociranosti izvan ljudskog uma. Ljudski um produkuje objektivnu duhovnost: umetničku sliku, muzičko delo, moralnost, pozitivno pravo. U aktu kreacije objektivne duhovnosti ili - što je isto - u aktu objektiviranja subjektivnog duha, dolazi do vezivanja tako objektivirane duhovnosti za nosioce: boju u slikarstvu,

6 Uporedi i Hegelovo razmatranje o pravu ropstva i gospodstva: „Sav historijski nazor o pravu ropstva i gospodstva, osniva se na stajalištu da čovjeka valja uzeti kao prirodno biće uopšte po nekoj egzistenciji [...] koja nije primjerena njegovu pojmu. [...] Stajalište slobodne volje, kojim počinje pravo i pravna znanost, već je iznad neistinitog stajališta na kojemu je čovjek kao prirodno biće [...] podoban za ropstvo." (Hegel, G. W. F.: Osnovne crte filozofije prava, Veselin Masleša - Svjetlost, Sarajevo, 1989, str. 111, § 57). 
notne znake ili zvuk u muzici, za jezik (slova i reči, odnosno glasove i reči) u pozitivnom pravu. Nosilac duhovnosti je u ovde nevedenim slučajevima izvan-duhovnog karaktera (boja, zvuk, grafički znak). ${ }^{7}$ Ako je akt objektiviranja pravni, uspostavljaju se stvari u pravnom smislu. Ako se pravno objektiviranje odvija na samom subjektu, tada nastaje lice. Covek u svojoj neposrednosti i pre i nakon apstrakcije u lice poseduje odredbu subjektivne duhovnosti, te se u aktu apstrakcije toj odredbi subjektivne duhovnosti dodaje odredba objektivne duhovnosti. Lice se tako razlikuje od stvari po tome što onaj nosilac (objektivne) duhovnosti jeste biće koje u svojoj strukturi sadrži subjektivnu duhovnost. Subjektivna duhovnost je ovde ono što je neposrednost i tek se posredovanjem putem apstrakcije dospeva do konstituisanja lica, ali je nosilac te apstrakcije, te specifično pravne duhovnosti, tog lica - taj nosilac je biće koje sadrži sloj subjektivne duhovnosti. To je smisao u kome možemo reći da je upravo subjektivna duhovnost princip diferencije lica i stvari kao pravnih instituta.

Pravnom institutu stvari do lica ,nedostaje" subjektivna duhovnost. ${ }^{8}$ Pravna određenost stvari, doduše neizostavno jeste duhovni fenomen, ali fenomen koji pripada isključivo svetu objektivnog duha. Bez duhovnosti uopšte ne bi bilo moguće govoriti o pravnosti, te je dakle nešto kao pravni pojam stvari izvan svake duhovnosti nemoguć po prirodi problema.

Stvar u sloju svog nosioca ne isključuje svaku duhovnost, nego samo subjektivnu. Autorska prava se odnose na duhovnost, ali je ta duhovnost bez izuzetka objektivna (slika, roman, filozofsko delo, muzičko delo). Predmeti autorskog prava su usled toga stvari a ne lica. Nije dakle svaka duhovnost isključena iz sfere stvari (u pravnom smislu), nego je to samo subjektivna duhovnost. ${ }^{9}$

Nepostojanje subjektivne duhovnosti kod stvari isključuje svaku mogućnost pravnog odnosa čoveka prema stvari. Ovo zbog toga što nije ono psihičko (volja) suština odnosa čoveka i stvari, nego ono duhovno. U protivnom bi odnos prema drugim živim vrstama ili odnos između životinja takođe mogli imati prirodu pravnog odnosa. To bi nadalje isključilo svaku mogućnost suštinskog razlikovanja lica i stvari.

Kada je reč o pravnom institutu stvari, pravna ravan se kao pravni odnos odvija uvek između lica a tek povodom stvari, dok je samo u izvan-pravnom, faktičkom smislu reč o neposrednom odnosu čoveka prema stvari. Situacija je analogna i u ekonomskom fenomenu gde se takođe bitna ravan onoga apstraktnog odvija između ljudi (gde do izražaja dolazi prometna vrednost), dok se neposredni odnos čoveka prema stvari ostvaruje tek u području upotrebne vrednosti. Sasvim drukčiju situaciju srećemo u jednom u ovom smislu bitno različitom duhovnom fenomenu $-\mathrm{u}$

7 Situacija je ovde doduše nešto složenija ali se to na ovom mestu neće iznositi jer nije od suštinskog značaja.

8 To je razlog zbog koga konj nikada ne može biti senator, kao i razlog što niko ne može odrediti psa za naslednika.

9 Razlika lica i stvari o kojoj je ovde reč dodatno ukazuje na udaljenost od pravog stanja stvari onih stanovišta koja pravnost ne vezuju za duhovnost, nego za volju. 
umetnosti. Ovde se suštinski umetnički akti - umetnička kreacija kao i umetnička recepcija - ostvaruju neposredno u odnosu čoveka prema objektu. Ovde dakle nije reč o odnosu između ljudi povodom stvari nego o neposrednom odnosu čoveka i stvari. Ova razlika je zasnovana na okolnosti na koju sam ovde već ukazao, naime na okolnosti da je u umetničkom fenomenu duhovnost uneta u materijalnost, dakle na tome što duhovnost prodire u objekat (,stvar"), dok se u pravnom fenomenu duhovnost samo apstraktno vezuje za materijalnost, ostajući na njenoj površini i samo prianjajući uz stvar u njenoj neposrednoj prirodnoj odredbi. Umetnost je duhovnost u čulnoj odredbi, pravo je duhovnost u duhovnoj odredbi. ${ }^{10} \mathrm{U}$ pravnom institutu stvari duhovnost se apstraktno unosi u prirodnost, u umetničkoj slici se duhovnost takoreći na prirodan, neposredan način unosi u materijalnost.

Ali nije samo „stvar" ono po čemu se u ovom smislu bitno razlikuju umetnički i pravni fenomen. Bitnu razliku srećemo i kada je reč o čoveku. Kada je glumčevo lice nosilac umetničkog dela, ono je sa stanovišta strukture umetničkog fenomena isto što i kamen u kiparstvu ili boja u slikarstvu. Njegova subjektivna duhovnost je samo jedno od sredstava, samo jedna podloga koja nosi - upravo jednako kao kamen u kiparstvu ili boja u slikarstvu. U pravnom fenomenu situacija je sasvim drukčija. Ovde je subjektivna duhovnost čoveka upravo kao duhovnost konstitutivna za fenomen, naime za jedan od fenomena, za lice kao institut prava. Subjektivna duhovnost čoveka je dakle konstitutivna komponenta za fenomen prava, dok je ona za fenomen umetnosti samo jedno od sredstava. Svakako da nema umetnosti bez subjektivnosti čoveka, bez nje nije moguć ni akt kreacije, ni akt percepcije umetničkog. Međutim, razlika je u tome što je subjektivna duhovnost samo jedno od sredstava i ne ulazi u sam predmet (u umetničko delo kao predmet), dok u pravnom fenomenu subjektivna duhovnost ima položaj konstitutivnog elementa lica kao pravnog instituta (kao samog predmeta onoga o čemu je reč). Razlika se svakako u ontološkom smislu zasniva na okolnosti da je pravo institut slobode (slobode čoveka kao duhovnog bića), dok je umetnost indiferentna prema slobodi kao institutu. Kada lice ipak u nekom pravnom poretku postane stvar, to je jasan i neosporiv znak da u tom poretku više nema autentičnog prava, tj. da je ono što se prikazuje kao pravo zapravo samo njegov privid a da je reč o poretku privilegija uređenom normama a ne o poretku prava i o autentičnim pravnim normama.

Čovek kao prirodno-duhovno biće u svojoj neposrednoj „prirodnoj” odredbi u pravni institut lica ulazi u celokupnom svom integritetu, dakle kao i priroda i kao duh istovremeno i moglo bi se reći komplementarno. Tako integralno shvaćena prirodna subjektivnost čoveka je ono što u sistemu autentičnog prava nikada ne može postati stvar. Kada ovo kažem,

10 Usled toga je očigledno netačno uobičajeno mišljenje da je umetnost „duhovniji” fenomen od prava - stvar je očigledno samo u tome što se u umetnosti duhovnost manifestuje neposrednije, naime putem čulnosti. 
ne iznosim neku tvrdnju čija suprotnost ne bi bila u skladu sa dobrim vaspitanjem ili najpravednijom pravdom, nego tvrdnju čija suprotnost ne bi bila u skladu sa zakonima ontologije. Dakle, tvrditi da lice nikada ne može postati stvar, nije pitanje pristojnosti nego filozofske istine. ${ }^{11} \mathrm{Iz}$ samog određenja, iz same definicije, dakle iz same prirode lica proizilazi da ono nikada ne može biti stvar zbog već više puta pomenute okolnosti da je licu subjektivna ljudska duhovnost konstitutivna komponenta i ujedno ono što ga upravo diferencira od stvari. Sa stanovišta pravnog fenomena, poreklo ontološkog razlikovanja lica i stvari počiva u okolnosti da je pravo institut slobode, da je samim tim pravo karakteristično samo za ljudski svet, samo za svet bića koja u svojoj strukturi obuhvataju subjektivnu duhovnost. Pravo je stoga uvek pravo čoveka, što implicira nužnost suštinskog razlikovanja lica i stvari. ${ }^{12}$

Što se tiče duhovnih tvorevina, samo objektivni duh može imati svojstvo stvari (npr. autorsko delo). Stvar u pravnom smislu - za razliku od stvari u čisto fizičkom smislu - nije dakle ono što neizbežno mora imati objektivnu fizičku, nego ono što neizbežno mora imati objektivnu duhovnu komponentu. Pravni je odnos prema stvari kao prirodi utoliko duhovnog karaktera. Dakle, kada se fizička stvar, uprkos njenoj čisto fizikalnoj prirodi, sagleda kao duhovni fenomen, ona postaje stvar u pravnom smislu.

Kao što je već rečeno, pravo je uvek pravo čoveka. Međutim, pravo se sa stanovišta svog predmeta vezuje ili za lica ili za stvari. Tako su dva osnovna instituta prava lice i stvar - iz njih se izvode svi ostali instituti prava. Stvar, dakle, nije temelj samo stvarnog nego celokupnog građanskog prava. To ujedno znači da nije svojina temelj građanskog prava, kao što se često smatra, nego je to upravo stvar.

Osnovni instituti koji se izvode iz stvari su stvarna prava, šteta, ugovor i sukcesija (singularna i univerzalna).

Osnovni institut stvarnih prava je svojina. Svojina obuhvata pravo držanja (ius possidendi), pravo korišćenja (ius utendi et fruendi) i pravo raspolaganja (ius disponendi).

Ako državina ima pravnu zaštitu ona je elemenat svojinskog prava. Državina koja nema pravnu zaštitu je detencija. ${ }^{13}$ Državina kao institut

11 „Jer, potrebno je da objasnimo prirodu prâva, a nju valja potražiti u prirodi čoveka." (Ciceron: Zakoni, Plato, Beograd, 2002, str. 19).

12 „Odsustvo principa identiteta objašnjava npr. (s obzirom da isti objekt može biti istovremeno on sâm i neko drugi) teškoću kojoj je izloženo primitivno biće da razumije otuđenje kao jasan prekid odnosa između otuđioca i njegove stvari." (Karbonije, Ž.: Pravna sociologija, Izdavačka knjižarnica Zorana Stojanovića, Sremski Karlovci - Novi Sad, 1992, str. 35).

13 „Opšti pojam državine u rimskom klasičnom pravu shvaćen je u vezi sa svojinom: držalac je onaj ko se prema stvari ponaša kao vlasnik; za državinu (possessio) potrebna su dva momenta: faktička vlast na stvari (corpus) i volja ponašati se prema stvari kao vlasnik (animus domini, animus rem sibi habendi). [...] Onaj ko stvar drži i koristi je ali nema ani- 
prava sadrži prirodnu (faktičku vlast na stvari) i apstraktnu odredbu za razliku od detencije koja je čisto prirodna neposrednost, kod koje apstraktna odredba izostaje. U tom smislu možemo reći da detencija nije pravna kategorija, ali je ona ipak značajna za pravni fenomen jer predstavlja izvan-pravni, neapstraktni pandan apstraktno-pravnom institutu državine. Detencija je fizičko, posed je duhovno (pravno) posedovanje stvari. Detencija pravnu zaštitu može imati tek posredno, preko državine. To znači da se lice sa detencijom radi eventualne pravne zaštite mora obratiti za pomoć licu u čije ime ima detenciju, tj. licu koje ima državinu i po tom osnovu mu je pravno omogućilo detenciju.

U pravu držanja kao elementu vlasničkog prava se apstraktna komponenta pravnog instituta vlasništva potiskuje iz vidokruga očiglednog i takoreći tone ispod površine onoga što je vidljivo. Time se stvara uobičajen privid da je pravo držanja, dakle državina kao elemenat vlasništva, ono što je neposredno prirodno $\mathrm{u}$ institutu stvari kao pravnom institutu. Tako je otvoren put kojim se dospeva do greške koja se proteže kroz celokupnu istoriju filozofije i koja je u nemačkoj filozofiji osamnaestog i devetnaestog veka takoreći omiljena - time je otvoren put za tzv. naturalističku grešku. Sasvim sažeto rečeno, stav koji je zasnovan na naturalističkoj grešci, koji ovde želim da osporim, može se izraziti na sledeći način: građansko pravo započinje vlasništvom a vlasništvo započinje posedom, pre svega okupacijom, nakon čega, u drugom momentu razvoja, posed prerasta u vlasništvo. Posed je po ovom stanovištu ono što je neposredno prirodno, koje se u svom sledećem momentu ontološkog razvoja ospoljava u vlasništvo, posed je kategorija koja prerasta u vlasništvo.

Naturalistička greška na čisto ontološkom planu sa zasniva na pogrešno uspostavljenom odnosu prirodnosti i duhovnosti. U pravnom i ekonomskom fenomenu ova greška dolazi do izražaja na samoj granici neposrednosti i apstrakcije. Naturalistička greška se sastoji u pokušaju izvođenja apstrakcije iz prirodnosti. U ekonomiji to podrazumeva pokušaj izvođenja prometne vrednosti iz upotrebne vrednosti a u građanskom pravu to najčešće podrazumeva izvođenje vlasništva iz poseda, tačnije rečeno iz detencije kao čisto faktičkog posedovanja stvari. Naturalistička greška nas vodi do pokušaja izvođenja građanskog prava izvorno iz stvari a ne iz lica, iako su sva prava uvek prava lica, dok su stvari samo njihovi mogući predmeti.

Naturalistička greška se zasniva na zabludi o mogućnosti neposrednog izvođenja duhovnosti iz materijalnosti. Reč je o pokušaju uspostavljanja takoreći kontinuiteta između materijalnog i duhovnog sloja bića. Duhovnost međutim ima jedan sasvim spoljašnji, naknadni odnos prema materijalnosti - duhovnosti se materijalnost javlja tek kao uslov, kao podloga njene egzistencije. To stanje stvari se najlakše uočava na području objektivnog duha, dakle u fenomenu duhovnosti koja je već objektivi-

mus u iznetom smislu, nema državinu već detenciju [...]." (Stanković, O. - Orlić, M.: Stvarno pravo, Službeni list SRJ, Beograd, 1994, str. 36). 
rana tako što je u produkciji ospoljena iz ljudskog uma i vezana za izvanljudsku materijalnost - za kamen, gips, papir, boju, ton, itd. Duhovni sloj se u fenomenima objektivnog duha onoj materijalnosti kao svojoj podlozi, kao svom nosiocu obraća spolja, duhovnost toj - takoreći svojoj - materijalnosti dolazi izvana. Materijalnoj strani jedne umetičke slike - platnu i boji - duhovnost dolazi izvana da bi se u nju unela i inkorporirala i tako stekla korpus onoga što postoji objektivno, nezavisno od ljudskog uma kao producenta, kao korpus onoga što je fenomen objektivnog duha. Tu prepoznajemo razliku prirodno lepog i umetnički lepog: prirodno lepo izvire iznutra iz samog predmeta, iz same materijalnosti kao takve, za razliku od umetnički lepog koje se u aktu produkcije umetničkog dela izvana unosi u materijalnost, koja ga prima i nosi u sebi kao izvan-fizički, dakle kao metafizički plan - upravo: kao duhovnost. Ono što je značajno da se ovde uoči je sledeće: duhovnost čak ni u umetnosti - uprkos tome što je u umetnosti reč o čulnoj odredbi duhovnosti - nikada ne izvire iz materijalnosti, nego joj uvek dolazi spolja.

Ta spoljašnjost iz koje duhovnost u objektivnom duhu pridolazi materijalnosti jeste subjektivna duhovnost. Kao što je već navedeno, odredba njene subjektivnosti označava samo njenu lokaciju, samo njenu smeštenost u ljudski um. Ali, ta okolnost nije od suštinskog značaja za njenu prirodu kao duhovnosti. To znači da je odnos duhovnog i materijalnog sloja u fenomenima subjektivnog duha izgrađen na onim istim principima na kojima je isti taj odnos izgrađen na području objektivnog duha. I zapravo treba misao ovde preusmeriti u obrnutom pravcu: duhovnost u sferi objektivnog duha sazdana je na istim principima svog odnosa prema svojoj materijalnoj podlozi, kao što je to i na području svog porekla, tj. subjektivne duhovnosti. To ne znači da se objektivni duh preslikava iz subjektivnog duha. Iz subjektivnog u objektivni duh (iz uma u umetničku sliku ili u pozitivno pravo) ne prenose se i ne preslikavaju se gotovi fenomeni objektivnog duha, niti njihovi obrasci. Ono što se zaista prenosi jeste sâm supstrat, sama materija od koje će se objektivna duhovnost graditi. Prenosi se dakle sama duhovnost kao takva.

U suštini je dakle odnos materijalnosti i duhovnosti i u fenomenima subjektivnog duha i u fenomenima objektivnog duha identičan. I u ljudskom umu srećemo diskontinuitet materijalnosti i duhovnosti i tek sa pojavom tog diskontinuiteta možemo govoriti o pojavi onoga čuda koje je duh i pred čijim mehanizmom nastanka zastaje dah. Cudo nastanka ne dovodi međutim u pitanje principijelni diskontinuitet dve sfere, što je na ovom mestu za nas jedino bitno.

$\mathrm{U}$ etici se naturalistička greška ${ }^{14} \mathrm{u}$ svom jasnom liku pojavljuje u eudajmonizmu i utilitarizmu, u religiji u svim varijantama tzv. prirodne religije, ${ }^{15}$ u ekonomiji u radnoj teoriji vrednosti, u ontologiji je u ovom smi-

14 Na problem naturalističke greške u etici je ukazao naročito Dž. E. Mur - uporedi: Mur, Dž. E.: Principi etike, Nolit, Beograd, 1963.

15 Prirodna religija je svojevrsna personifikacija pojedinih prirodnih fenomena u bogove, te u tom smislu Ludvig Fojerbah piše , ,[...] da je suština prirodne religije - priroda, da se u prirodi i u prirodnoj religiji ne otkriva i ne odražava ništo drugo do sama priroda". 
slu izrazit primer prelaska kvaliteta u kvantitet (kod Hegela $\left.{ }^{16}\right)$. Pravni fenomen je naturalističkom greškom opterećen u svim teorijama prirodnog prava ali i u nekim savremenim teorijama koje nisu prirodno-pravne, kao što je na primer Rolsova teorija pravde, koja je pravna varijanta eudajmonističke etike. Istorijski posmatrano, naturalistička greška počinje sa prvom pojavom duha s obzirom da je u fenomenu mita, kao prvom istorijskom fenomenu duhovnosti, isprepletanost - a to ovde znači nerazlikovanje i konfuzija - prirodnosti i duhovnosti jedna od osnovnih karakteristika tog fenomena. U mitu su priroda i duh jedno isto, ljudski um tu još nije spoznao njihovu razliku. Time je u mitu naturalistička greška dovedena do svoje krajnje konsekvence, bolje rečeno, ona ovde postoji u svom savršenom, neokrnjenom obliku koji nimalo nije doveden u pitanje. Daljim razvojem duhovnosti kroz istoriju, razlika prirodnosti i duhovnosti, odnosno materijalnosti i duhovnosti sve više dolazi do izražaja ali je naturalistička greška koja čini pun sadržaj mitske svesti do danas ipak ostala neprevaziđena iako je razvoj duhovnosti išao za tim da to učini.

Ako se za poreklom vlasništva traga u posedu, tada nas je na taj pogrešan put dovela upravo naturalistička greška. Početak građanskog prava je zaista u stvarnom pravu ali to nikako ne znači da stvar u svojoj pravnoj odredbi, dakle stvar kao institut pravnog fenomena, svoje istinsko poreklo nalazi u faktičkom odnosu čoveka prema stvari, dakle u detenciji. ${ }^{17}$ Kao što je već navedeno, stvarno pravo se ne zasniva na stvari kao onome što je neposredno, kao onome što je prirodno, nego na licu kao onome što je posredovano apstrakcijom. Lok je na jasnom stanovištu koje je ovde označeno kao naturalistička greška kada, pišući o svojini, navodi: „Što god tada uzme iz stanja koje je pružila i u njemu ostavila priroda, on (čovek) je tome dodao svoj rad i pridodao nešto što je njegovo vlastito, čime je to učinio vlastitom svojinom."18 Kod Hegela razvoj duha u pravnoj sferi započinje posedom, te je i njegovom shvatanju formiranja građanskog prava, odnosno uspostavljanja stvari kao pravnog instituta, svojstvena naturalistička greška. S druge strane, Kant sasvim jasno navodi da „ne postoji, shvaćeno stvarno i doslovno, nikakvo (direktno) pravo u nekoj stvari, nego se samo tako naziva ono koje nekome pripada prema osobi koja je sa svima ostalima (u građanskom stanju) u zajedničkom posedu". ${ }^{19}$ Očigledno je da Kant, za razliku od pomenutih velikih filozofa, nije zapao u naturalističku grešku. Kant je naturalističku grešku kod odre-

S druge strane, „hrišćanska religija se ne oslanja na čula, već [...] na reč, na slovo božje [...]" (Fojerbah, L.: Predavanja o suštini religije, BIGZ, Beograd, 1974, str. 171, odnosno str. 180).

16 Mislim pri tome na prvu knjigu Hegelove Logike koja je po svojoj suštini u stvari ontologija.

17 U tom smislu čitamo kod Pašukanisa: „Odnos čovjeka i stvari sam je po sebi lišen svakog juridičkog značenja." (Pašukanis, J. B.: Opća teorija prava i marksizam, u knjizi: Sovjetske teorije prava, Globus, Zagreb, 1984, str. 237).

18 Locke, J.: Dve rasprave o vladi, II, Mladost, Beograd, 1978, str. 24.

19 Kant, I.: Metafizika morala, Izdavačka knjižarnica Zorana Stojanovića, Sremski Karlovci, 1993, str. 63 (§ 11). 
đenja stvari izbegao zahvaljujući tome što on pravo izvodi iz poretka, ali pošto on iz poretka izvodi celokupno a ne samo građansko pravo, to ga je s druge strane dovelo do pogrešnog određenja lica. ${ }^{20}$

Pravni institut stvari jednako nastaje unošenjem duhovnosti u stvarnost, vezivanjem duhovnosti za stvar - vezivanjem koje je toj stvari spoljašnje, kao što i u umetničkom fenomenu lepota slike nastaje tek spoljašnjim vezivanjem duha za boju ili kao što lepota muzike nastaje spoljašnjim vezivanjem duha za ton koji proizvodi violina. Paradoksalno je međutim to što estetika već vekovima razlikuje prirodno lepo i umetnički lepo takoreći uprkos tome što u umetnosti duhovnost prodire u materijalnost kao u svog nosioca, dok s druge strane filozofija prava već vekovima uporno ignoriše istu tu razliku prirode i duha - i to takoreći uprkos tome što ovde duhovnost ne prodire u prirodnost nego uz nju samo prianja (kako je ranije navedeno). Pokušaj izvođenja svojine iz poseda, isto je naime što bi bio pokušaj izvođenja umetnički lepog iz prirodno lepog, što bi bio pokušaj izvođenje duhovne religije iz prirodne (ili iz panteizma), isto što je izvođenje moraliteta iz prirodnosti a u ekonomiji prometne vrednosti iz upotrebne, te najzad isto što i izvođenje kvantiteta iz kvaliteta a apstrakcije iz prirodnosti u logici, odnosno u ontologiji.

Paradoks je utoliko veći što je upravo u pravnom (i ekonomskom) fenomenu u stvari lakše uočiti spoljašnjost porekla duha u odnosu na stvar kao prirodu i materijalnost. U svakom slučaju to bi trebalo da bude lakše nego u onim fenomenima u kojima se duhovnost ne pojavljuje u svojoj apstraktnoj odredbi, kao što je slučaj sa umetnošću ili jezikom.

U prvom aktu formiranja stvari, njoj je prirodnost sasvim irelevantna po svom prirodnom sadržaju i svodi se na pukog nosioca duhovnosti, na jednostavnu podlogu onoga što je duh. Tako se svojina najpre određuje kao nešto sasvim udaljeno od prirodnosti, njoj nešto sasvim indiferentno, dakle kao puka imovina. ${ }^{21}$ Nije dakle posed nego imovina ono čime u jednom suštinskom smislu započinje formiranje instituta svojine. Ne počiva dakle svojina na posedu, nego se zasniva svojina na imovini a posed je tek naknadna odredba jednog i drugog. Sve ovo je sasvim logična i neizbežna konsekvencija okolnosti da pravna odredba stvari počinje daleko od same stvari kao prirode, da ona počinje u licu kao subjektivnoj duhovnosti.

Stvar je dakle u pravnom fenomenu najpre čista apstrakcija, u pogledu prirode sasvim nerazlikovana u sebi i utoliko imovina kao čisto apstraktna odredba svojine. Objektivna duhovnost koja još nije vezana ni za jednu prirodnu stvar, koja je time takoreći pogodna za svaku stvar, koja se stvari kao prirodnosti obraća tek kao jedno „treba da”, kao jedno trebanje (das Sollen), jeste imovina. Imovini kao duhovnosti još nijedna prirodna stvar ne pripada individualno kao njen nosilac, ali imovina usled toga nikako ne lebdi izvan svake materijalnosti i stvarnosti, ona ne lebdi

$20 \mathrm{Na}$ to sam ukazao u već pomenutom članku o konstituisanju lica.

$21 \mathrm{U}$ pozitivno-pravnom smislu te reči. 
u nekom prostoru koji ne bi ispod sebe imao nosioca u svetu materijalnosti. Samo što njen nosilac, njen svet materijalnosti koji je nosi, jeste njoj još uvek sasvim irelevantan po svom prirodnom sadržaju, te je dakle imovina prema pojedinačno određenoj prirodnosti svog nosioca sasvim indiferentna, jednako kao što je novac po svojoj suštini indiferentan prema prirodnosti koja njega nosi (prema prirodnosti papira ili metala novčanice). Stepen apstrakcije instituta imovine u građanskom pravu jednak je stepenu apstrakcije instituta novca u ekonomiji. U tom smislu zapravo možemo reći da je imovina svojina svedena na njenu prometnu vrednost, odnosno da je imovina svojina bez upotrebne vrednosti. Imovina je upravo nešto sasvim suprotno detenciji. Ili, kako piše Radbruh, „u imovini se svojina denaturiše". ${ }^{22}$

Kada se imovini definiše individualni prirodni sadržaj, kada se ona više ne vezuje za stvar kao takvu, nego za jednu određenu stvar - ona prerasta u svojinu. Svojina je integralna, celovita egzistencija stvari kao pravnog instituta - ona $s$ jedne strane obuhvata apstraktnu a $s$ druge strane prirodnu odredbu.

Potrebno je medutim naglasiti da ona prirodna odredba pravnog instituta stvari o kojoj je ovde reč, nikako nije ograničena na materijalnost. Taj izvan-apstraktni, taj tek u tom izvan-apstraktnom smislu prirodni sadržaj pravnog instituta stvari, vrlo često je sasvim nematerijalnog karaktera, tj. vrlo često je to duh, kao što je to slučaj sa celokupnim područjem tzv. intelektualne svojine. Zbog toga mi ovde kada kažemo ,prirodna odredba stvari" zapravo ne mislimo na prirodnost u jednom grubo materijalnom smislu, nego na prirodnost kao celokupno područje onoga što nije apstraktno. Prirodnost u ovom smislu obuhvata i duhovnost koja nije apstraktna. Duhovnost se u stvari (kao institut prava) pojavljuje u obe odredbe - kao prirodnost i kao apstrakcija. Roman i simfonija su duhovni fenomeni koji u sebi ne sadrže ništa apstraktno jednako kao što to ne sadrži i gruba materijalnost kuće ili zemljišta. Uspostavljanjem stvari kao pravnog instituta, gruboj materijalnosti kuće i zemljišta, kao prirodnosti, dodaje se apstraktna odredba i na taj način dolazi do nastanka svojine na kući i zemljištu. Ali, strukturalno i suštinski ontološki na isti način se i onoj neposrednoj, i u tom smislu prirodnoj duhovnosti romana i simfonije izvana dodaje pravna apstraktna odredba i na taj način dolazi do nastanka „autorske svojine" na romanu i simfoniji. Duhovnost se dakle u stvari može pojaviti u dva sasvim različita sloja - u njenom pravnom određenju, kao ono što je apstraktno utoliko što je indiferentno prema onome neposrednom (romanu, simfoniji), ali i u njenom neposrednom određenju koja se toj pravoj spoljašnjosti javlja kao nosilac, kao ono što je takoreći prirodnost, naime ono čemu je njegova vlastita diferenciranost relevantna kao takva (roman, simfonija, autorsko delo uopšte).

22 Radbruh, G.: Filozofija prava, Nolit, Beograd, 1980, str. 177. 
Kao što je poznato, svojina obuhvata pravo raspolaganja, pravo držanja i pravo korišćenja. Pravo raspolaganja je pri tome neophodan sadržaj svakog svojinskog prava, dok to nisu ni pravo držanja ni pravo korišćenja. To ujedno podrazumeva da se pravo držanja i pravo korišćenja mogu prenositi na druga lica, bez prenošenja prava vlasništva, odnosno da se ta prava mogu formirati kao stvarna prava na tuđoj stvari (iura in re aliena). Pravo raspolaganja se na tuđoj stvari nikada ne može formirati kao potpuno jer formiranje potpunog prava raspolaganja na tuđoj stvari podrazumeva prenošenje samog vlasništva, dakle gubitak svojstva ,tuđe stvari” za nosioca tog prava.

Kada je reč o pravu raspolaganja, koje dakle može postojati samo na vlastitoj stvari - njemu se kao pandan na tuđoj stvari javlja založno pravo. U tom smislu možemo slikovito reći da kada pravo raspolaganja pređe na tuđu stvar, ono se pretvara u založno pravo. Založno pravo je pravo raspolaganja isključivo i uvek na tuđoj stvari i ono se u pravnom smislu nikada ne formira kao celovito pravo raspolaganja jer nikada ne obuhvata pravo faktičkog nego samo pravnog raspolaganja, tj. otuđenja.

Na taj način, kada dospemo do odnosa prava raspolaganja vlasnika stvari s jedne strane i prava raspolaganja koje založni poverilac ima na tuđoj stvari s druge strane, dotakli smo tačku krajnjeg razlikovanja stvarnih prava na vlastitim stvarima s jedne strane i na tuđim stvarima s druge strane. To je ujedno tačka razlikovanja svojinskog prava s jedne strane od svih ostalih, ne samo stvarnih, nego i svih građanskih prava s druge strane.

Pravo svojine je jedini institut u kome se, nakon napuštanja područja lica i prelaska na područje stvari, u punoj meri srećemo sa istinskom prirodom prava. Pravo je institut slobode. Ovakvo određenje prava u punoj meri dolazi do izražaja kada je reč o licu kao institutu prava. Ovakvo određenje prava - kao jedino njegovo autentično određenje - podrazumeva naravno nesagledivo bogatstvo značenja, ali je u kontekstu u koji smo ovde dospeli najznačajnije ono značenje po kome sloboda kao institut pravnog fenomena podrazumeva granicu kao svoju poleđinu (jer je navodna sloboda bez granice jednostavna i jednostrana neodređenost koja se kroz psihičko područje volje proteže kao proizvoljnost). Kada se iz sfere lica pređe na teren stvari, gubi se jasan bljesák slobode, njena se očiglednost potiskuje u drugi plan jer je dužnost ono što se ističe $\mathrm{i}$ što ima primat $\mathrm{u}$ institutima građanskog prava. Ali - sa izuzetkom instituta svojine.

U svojini se - slično kao i u licu - institutu, dakle određenosti prava, pristupa iznutra. U institutu svojine se stvar kao pravo takoreći razvija iznutra iz same stvari, što naravno ne može biti istinito ali je crta tog privida ipak veoma naglašena - privida koji nam se mora dopasti jer je koristan za razjašnjenje problema. Kao što sam prilikom razmatranja lica naglašeno naveo, jedino se u pravnom fenomenu sloboda određuje kao institut, kao puna određenost a ne tek razdragana igra, jer samo u pravnom fenomenu sloboda se u svom legitimnom naličju oslanja na granicu. 
ka. Dakle tajna je u tome i jedino u tome što je upravo izneto: da je u institutu svojine sloboda ono što je prvo a granica ono što tek nadolazi izvana. Upravo zbog toga svim stvarnim pravima - kao onima koja se bez izuzetka oslanjaju na svojinu - logički pripada dejstvo erga omnes, dakle jedno dejstvo koje od svojine preuzima onu osobinu prostiranja iznutra iz same stvari, iz njenog unutrašnjeg prirodnog beskraja, iz same slobode koja je u unutrašnjost te stvari dospela iz lica.

Stvarna prava na tuđim stvarima, koja sva bez izuzetka toj stvari kao onom što je tuđe time prilaze spolja, koja tu apstraktnu granicu u jednom suštinskom smislu po svojoj prirodi nikada ne mogu da prekorače, ta stvarna prava se ipak na onu unutrašnjost stvari kao svojine oslanjaju kao na svoju podlogu, kao na svoje uporište do koga su dospela i sa koga se nakon toga obraćaju svima oko sebe - kao da je na toj apstraktnoj granici svojine došlo do svojevrsne refleksije (u jednom fizikalnom smislu) u kojoj se odvio akt suštinskog osnaženja njihovog prava na tuđoj stvari. Pravo koje je dotle bilo obligaciono, kao ono što deluje inter partes, sada je postalo stvarno, kao ono što deluje erga omnes, kao ono što je iz unutrašnjosti stvari kao svojine ,povuklo" snagu onoga što deluje iznutra, što je priroda, što je sloboda. Na tome se zasniva legitimnost dejstva erga omnes koje pripada svim stvarnim pravima na tuđim stvarima.

Čak i kada se vlasnikovo pravo na stvari onim stvarnim pravima drugog lica optereti i suzi u toj meri da njemu kao vlasniku ostane nuda proprietas, čak i tada njegovo pravo sa ovde iznetog suštinskog aspekta nije pretrpelo nikakvu promenu - i u vlasništvu kao nuda proprietas vlasništvo je najpre sloboda a tek naknadno granica, najpre pravo a tek naknadno dužnost. Moglo bi se reći da je nuda proprietas situacija u kojoj je vlasniku stvar u jednom empirijskom smislu potpuno izmakla, dok mu je i dalje u tom prostoru njegove stvari ostala sloboda, sada tek kao princip. U protivnom, on više ne bio vlasnik, odnosno bio bi vlasnik ničega, što je svakako protivrečnost koja bi institut nuda proprietas učinila nemogućim i sasvim besmislenim.

Fihte smatra da ,temelj svakog prava svojine treba staviti u pravo da se svi isključe iz izvesne slobodne delatnosti koja je rezervisana jedino za nas, a nipošto u isključivo posedovanje objekata". ${ }^{24}$ Očigledno da Fihte time naglašava socijalni karakter instituta svojine, ${ }^{25}$ sa čime se svako treba složiti. Na socijalnom karakteru svojine insistira i Kant: „Besmisleno je zamišljati neku obvezanost jedne osobe prema stvarima i obrnuto, mada u svakom slučaju može biti dopušteno taj pravni odnos učiniti očiglednim takvom slikom i tako se izraziti."26 Ipak je međutim potrebno ukazati na to da su svi instituti prava socijalni fenomeni, kao što je to uostalom ce-

24 Fihte, J. G.: Zatvorena trgovačka država, Nolit, Beograd, 1979, str. 61.

25 „To što neko dobija nešto u svojinu, događa se samo zato da bi se rešio spor više njih o tome istom. O svojini nekog čoveka koji živi izolovano na nekom ostrvu uopšte se ne može govoriti." (Ibid., str. 60).

26 Kant, I.: Metafizika morala, Izdavačka knjižarnica Zorana Stojanovića, Sremski Karlovci, 1993, str. 63. 
lokupnost pravnog fenomena, i kao što su to i svi ostali instituti drugih duhovnih fenomena putem kojih se institucionalizuju društveni odnosi (politika, ekonomija, moral). Dakle, socijalna priroda svojine nije ništa što bi samo za ovaj institut bilo specifično i što bi ga na taj način - pa makar i negativno - moglo zaista odrediti. Naglašavanje socijalnog karaktera instituta svojine više je potrebno zbog starijih shvatanja svojine kao prirodnog odnosa čoveka prema stvari (teorija okupacije, teorija ra$\mathrm{da}^{27}$ ). Stvarna prava na tuđoj stvari su nesporno i neosporno takođe socijalni instituti ne manje od svojine, ali je ipak njihova razlika u odnosu na svojinu suštinska i ne može se pronaći u socijalnom poreklu svojine. Hoću da kažem da Fihte i Kant govore o onome što je doduše tačno ali ipak ovom problemu nešto sasvim spoljašnje. Stoga je suštini instituta svojine mnogo bliži Radbruh kada piše da ,[...] sadržinski ograničena stvarna prava ne mogu uz to doći u obzir kao prava na vlastitoj nego samo na tuđoj stvari". ${ }^{28}$ C̆ak ni Hegel, koji je celokupno pravo sagledavao preko kategorije slobode, ne razvija pravo raspolaganja kao ono u čemu je sloboda primarna, nego on ono što je za vlasništvo suštinsko traži u posedu „da ja imam nešto u svojoj čak spoljašnjoj vlasti, u tome se sastoji posjed [...] No ta strana da sam ja sebi kao slobodna volja u posjedu predmetan, a time također tek zbiljska volja, sačinjava ono istinsko i pravno u tome, određenje vlasništva". ${ }^{29}$ Hegel dakle ono što je za slobodu u ovom kontekstu odlučujuće određuje kao volju a ne kao duh, te ni njegovo određenje već usled toga ne može da dospe do onoga što je suština instituta svojine. ${ }^{30}$ Kritikom ovih stanovišta nisam naravno pokušavao da umanjim njihov značaj za određenje pojma svojine u jednom istorijskom smislu razvoja duha, odnosno razvoja pojma svojine.

Treba ovde napomenuti i to da se naravno ne može osporiti činjenica da granicu svojinskom pravu ne postavljaju samo tuđa prava na toj stvari, nego i ograničenja koja su izvan same te stvari. ${ }^{31}$ Reč je o primeni

27 Teorija okupacije i teorija specifikacije (rada) su po svojim krajnjim konsekvencama više sociološke nego pravne teorije svojine. Naime, sve pojedinačne teorije koje se mogu podvesti pod ove dve u stvari se ne bave pojmom vlasništva nego tek jednim njegovim kvalitetom - njegovom opravdanošću, odnosno pravednošću. Svaka teorija opravdanosti vlasništva pripada pre svega sociologiji prava, dok filozofiji prava pripada samo ona teorija koja se bavi samim ontološkim određenjem pojma vlasništva. I Radbruh misli sociološki kada, doduše s pravom, piše: „Svojstvo uzajamnosti robnog tržišta stvorilo je i uzajamno priznavanje svojine. Dok je u zatvorenoj kućnoj privredi svaka privredna jedinica bila sama sebi dovoljna, svojina je bila više odnos prema nekoj stvari nego odnos prema drugim ljudima." (Radbruh, G.: Filozofija prava, Nolit, Beograd, 1980, str. 179).

28 Ibid., str. 171.

29 Hegel, G. W. F.: Osnovne crte filozofije prava, Veselin Masleša - Svjetlost, Sarajevo, 1989 , str. 95 (§ 45).

30 Kritikom Hegelovog shvatanja prava kao volje bavio sam se u članku Konstituisanje lica.

31 „Moglo bi se zamisliti da neki tvrdica, koji ni za života ni posle smrti neće da ikome nešto pokloni, u svoj testament unese odredbu da se njegove hartije od vrednosti i dragocenosti polože zajedno s njim u grob ili da se unište. Sa stanovišta individualističkog shvatanja svojine takva bi se odredba morala izvršiti, ali prirodno osećanje će svakom reći 
na stvar, odnosno na institut svojine one iste granice koja se u opštem smislu uspostavlja i ostaje stalna a nalazi se između slobode i proizvoljnosti. Dakle, vlasnikovo pravo raspolaganja je neograničeno u smislu instituta slobode u pravnom smislu te reči a ne u smislu proizvoljnosti koja pada izvan slobode i prava. I ovde je vidljivo da granica koja se postavlja slobodi nije nešto što toj slobodi protivreči nego nešto što je upravo određuje, ne nešto što je negira, nego nešto što je definiše $\mathrm{i}$ afirmiše.

U dosadašnjoj filozofiji prava su najviše pristalica imale dve teorije o prirodi vlasništva: teorija okupacije i teorija kreacije (specifikacije). ${ }^{32}$

Orginerno sticanje je uspostavljanje stvari kao pravnog instituta ali takvo uspostavljanje koje se odvija na empirijski pojedinačnoj stvari, a ne principijelno na stvari kao takvoj. Uspostavljanje pravnog instituta stvari u pojedinačnom empirijskom slučaju (okupacija, kreacija) je orginerno uspostavljanje vlasništva (kao sticanje), s druge strane, uspostavljanje stvari kao takve, bez vezivanja za empirijski pojedinačnu stvar, jeste akt ontološkog stvaranja instituta svojine. Ovo je veoma bitno razlikovanje: ono otklanja vekovnu zabludu da svojina kao takva počinje sa detencijom jer naime samo svojina na empirijski pojedinačnoj stvari počinje sa detencijom. Orginerno sticanje nije nastanak vlasništva kao takvog, to nije ontološki nego empirijski akt. Sticanje - jednako orginerno kao i derivativno - samo je akcidencija vlasništva, odnosno stvari, dok su kao pravni instituti vlasništvo i stvar nastali pre svakog akta sticanja vlasništva na empirijskoj stvari i pre svakog akta koji stupa u empirijsku egzistenciju. U ovom smislu je detencija sasvim profana pojava, sasvim nepravni fenomen - što je u teoriji pozitivnog prava odavno shvaćeno i takoreći nesporno, ali to filozofija prava do sada nije primećivala. Detencija postoji i u prvobitnoj zajednici, gde još nema ni prava ni lica a samim tim ni stvari kao pravnog fenomena. Detencija je u prvobitnoj zajednici moguća upravo zbog toga što je reč o izvan-pravnom, takoreći pred-pravnom fenomenu. Tek kada se proizvoljnosti odredi granica, kada tako prirodni čovek preraste u apstraktno lice, uspostavlja se ontološki temelj za fenomen prava i tek nakon toga se formira stvar kao institut tog fenomena (prava).

Pogrešnom određivanju mesta okupacije i kreacije, odnosno detencije u formiranju instituta vlasništva, odnosno stvari odlučno je doprineo paralogizam koji se sastoji u izostanku uspostavljanja jasne razlike između empirijskog i ontološkog aspekta stvari, odnosno u neprekidnom i nejasnom prelasku iz jednog u drugo. Naime, neosporno je da na svakoj pojedinačnoj empirijski postojećoj stvari vlasništvo nastaje ili okupacijom ili kreacijom - što znači da je akt nastanka vlasništva na empirijski pojedi-

da se to ne može dopustiti, a tako odlučuje i rimsko pravo [...] Dakle, nije istina da svojina po svojoj „ideji” u sebi uključuje apsolutnu vlast raspolaganja.” (Jering, R.: Cilj u pravu, CID, Podgorica, 1998, str. 226-227).

32 Uporediti na primer: Radbruh, G.: Filozofija prava, Nolit, Beograd, 1980, str. 172. 
načnoj stvari uvek neizbežno vezan za detenciju. Na ovu neosporno tačnu okolnost su se oduvek oslanjale sve teorije vlasništva koje su kao prvu odredbu vlasništva videle posed kao ono što je pravni lik detencije. Međutim, pri tome se previđa da su stvar i vlasništvo apriorne kategorije duha, kao što su to i svi temeljni instituti pravnog fenomena. Apriornost tih kategorija se sastoji u tome što se one na kao ontološki fenomeni uspostavljaju pre stupanja u empirijsku sferu a to ovde znači pre svakog pojedinačnog vezivanja za empirijski postojeće pojedinačne stvari. Ontološki posmatrano, najpre se formira institut stvari i institut vlasništva a tek tako formiran, ontološki dovršen institut se može vezati za ontološki već zatečenu, od pravnog fenomena nezavisnu prirodnu, empirijsku stvar. Dakle, prirodna odredba stvari (njena upotrebna vrednost, rekli bi ekonomisti) sasvim je u svom prirodnom biću nezavisna od svoje apstraktne određenosti u pravnom ili ekonomskom fenomenu, dakle od svog lika robe ili stvari (kao pravnog instituta) odnosno vlasništva. U istoj meri - dakle potpuno - je nezavisnost zastupljena i u suprotnom smeru: i apstraktna određenost stvari kao pravnog instituta u svojoj duhovnoj prirodi sasvim je nezavisna od njoj ontološki sasvim irelevantnog naknadnog vezivanja za empirijski pojedinačne stvari. To vezivanje je u istorijskom smislu svakako od sudbinskog značaja kako za prirodnu, tako i apstraktnu odredbu stvari - ali, ontološka nezavisnost se time ne dovodi u pitanje.

Vezivanje duhovnog instituta stvari (u pravnom smislu) i vlasništva za prirodne pojedinačne stvari nije dakle početak nego kraj u procesu nastanka vlasništva. U apriornoj sferi vlasništvo nastaje kao institut a u empirijskoj sferi, u kojoj se ono naknadno vezuje za empirijski pojedinačne stvari, taj apriorni metafizički institut stupa u empirijsku egzistenciju. Dakle, sve vreme je reč o razlikovanju onoga što je ontološko i onoga što je istorijsko, onoga što je metafizičko i onoga što je „fizičko”, onoga što je ovde suština i onoga što je ovde pojava. Nerazlikovanje ovih kategorija kroz celokupnu dosadašnju istoriju je proizvodilo i održavalo aporije do kojih se dospevalo u objašnjenju prirode vlasništva a koje aporije su oduvek bile rezultat paralogizma.

Pravnim institutima stvari i vlasništva se nikada ne sme pristupati sa aspekta prirodnih stvari. Pravni institut stvari nije institut prirodne stvari nego apstraktnog prava, što znači da pravni institut stvari svoje istinsko ontološko poreklo nema u prirodnoj stvari nego u apstraktnom institutu lica (podsetimo: pravo je uvek pravo čoveka). Teorija okupacije i teorija kreacije, ${ }^{33}$ kao dve najrasprostranjenije teorije vlasništva, upravo ovu temeljnu stvar previđaju. Svemu pak treba da prethodi jasno razlikovanje pojma stvari s jedne strane i pojma lica s druge strane i svakako jasno shvatanje njihove suštinske ontološke razlike. Mora se jednom zauvek shvatiti da razlikovanje lica i stvari za pravni fenomen nije pitanje pristoj-

33 Teorija kreacije kao pravna teorija, isto je što i teorija radne vrednosti kao ekonomska teorija. U ovom članku već izneto osporavanje naturalističke greške treba svakako primeniti i na ove teorije. 
nog odnosa prema čoveku kao ljudskom biću nego je to pitanje ontološke zakonitosti.

Pravo mesto svih teorija koje se oslanjaju na detenciju možda se najlakše može objasniti ukazivanjem na nešto što bismo mogli nazvati orginernim načinom prestanka vlasništva - na zastarelost kao način prestanka prava vlasništva (čija je druga strana održaj, što međutim ovde nije bitno). Zastarelost prava vlasništva, svojevrstan orginerni način prestanka vlasništva, ne nastupa dugotrajnim izostajanjem detencije, kao što bi to moralo biti da su „orginerne teorije vlasništva” tačne. Onaj uslov koji se istinski mora ispuniti jeste izostajanje svih pravnih manifestacija vlasništva, kao što su posed, korišćenje, raspolaganje a ne izostajanje izvan-pravnih, pred-pravnih katerogija, kakva je detencija. ${ }^{34}$ Kada je reč o detenciji, njena sledeća - prva pravna - odredba je svakako posed. U ovom kontekstu treba dakle istaći da u meri u kojoj se zastarelost vlasništva vezuje za držanje stvari, ta se zastarelost uvek vezuje za posed kao ono što je kategorija pravnog fenomena a nikada za detenciju kao ono što je izvan-pravni fenomen. Upravo $u$ istoj onoj meri u kojoj se i druga strana zastarelosti prava vlasništva, naime održaj kao naročit orginerni način sticanja vlasništva nikada ne vezuje za detenciju, nego sa stanovišta držanja stvari uvek isključivo za posed. U savremenim uslovima sve izraženijeg razdvajanja prava raspolaganja s jedne strane i prava korišćenja i držanja s druge strane, to čak postaje očigledno.

Kratko rečeno, nije sticanje vlasništva ono u čemu se sastoji suština instituta vlasništva, nego je to uspostavljanje stvari kao instituta pravnog fenomena. Sticanje vlasništva na pojedinačnim empirijski postojećim stvarima je samo empirijska manifestacija instituta koji je prethodno formiran u metafizičkoj sferi.

Istorijski posmatrano, može se uiočiti da se stvar u prvom pravnom dobu - u robovlasništvu - još ne shvata na jasan i određen način i razlika između lica i stvari još nije uspostavljena kao ono što ima prirodu ontološkog zakona. Razlog tome je to što se ovde pravo još shvata kao u suštini operativno-tehničko sredstvo, kao jedna spoljašnja pravilnost a ne kao sloboda. Stoga se pravo u robovlasništvu pojavljuje samo u svom $l i$ $k u$ prava, u svojoj pojavi a ne u svom istinskom sadržaju, u svojoj suštini. Pravilnost je lik, dok je samo sloboda suština prava. Bez određenja prava kao slobode, nije moguće jasno razlikovanje lica i stvari, te se usled toga i lica mogu odrediti kao stvari, kao res cogitans. ${ }^{35} \mathrm{~S}$ obzirom da pravo u

34 Kao što je poznato, posed koji se manifestuje tek posredno, preko drugog lica, sasvim dovoljno štiti vlasnika stvari od prestanka prava vlasništva održajem. Posredna državina je pak državina bez detencije. Dakle, posredna državina, državina bez detencije, sasvim dovoljno štiti vlasnika od održaja.

35 „Sada bih rekao o stvarima koje služe za obradu zemlje. Neki ih pisci dele u dve grupe, na ljude i na ono čime se ljudi služe, bez čega je nemoguća obrada zemlje. Drugi dele na tri grupe: oruđa koja govore, koja muču i nêma; koja govore - to su robovi, u ona 
robovlasništvu još ostaje samo na površini, samo na nivou lika prava a ne njegove suštine, $\mathrm{s}$ obzirom da se pravo ovde još ne određuje kao institut slobode, to ono, bez obzira na svoju neospornu tehničku razvijenost i preciznost, koja je naročito došla do izražaja u rimskom građanskom pravu, ipak ne dospeva do onoga što je bitno. Tako je razvijeno građansko pravo robovlasničkog Rima samo jedan dragocen materijal za ono što u istoriji tek predstoji - formiranje autentičnog prava kao instituta slobode. Taj će se istorijski obrt desiti tek u građanskom društvu, gde se čovek definitivno konstituiše kao lice a stvar uspostavlja kao apstraktni institut prava.

U prvobitnoj zajednici ne postoji pravo a samim tim ni stvar kao pravni institut. Od kategorija budućeg građanskog i stvarnog prava postoji samo detencija koja naravno još ni najmanje nije nešto pravno, ali je ono nešto što je kao izvan-pravno najbliže budućim institutima građanskog prava. U robovlasništvu se stvar i lice ne razlikuju jer se pravo ne shvata kao sloboda, te se usled toga subjekt ne shvata kao ono što je primarno i samim tim je moguć institut res cogitans. U feudalizmu se odvija prelaz između prethodnog perioda ka sledećem - putem srednjeg socijalnog sloja (koji će kasnije prerasti u građansku klasu) ide se za tim da se pravo prevaziđe kao feudalno pravo koje je shvaćeno isključivo kao privilegija, kao privilegija vlasnika stvari. $U$ feudalizmu tako ne postoji lice kao instinski institut prava i u tom smislu možemo reći da u feudalizmu dominira stvar a ne lice. Tek sa građanskim društvom dolazi do jasnog i potpunog razlikovanja lica i stvari a to znači određivanja prava kao slobode. Eksperimenti socijalizma su se u ovom smislu sveli na ponovno ukidanje lica u kategoriji kolektivizma i ovde je istovremeno došlo i do ukidanja stvari u institutu državne i društvene svojine, dok se sâmo pravo opet svodi na privilegiju, sada na privilegiju elitnih pripadnika kolektivu (partiji). U tom smislu možemo reći da u socijalizmu dominira kolektiv naspram lica i stvari, da dominira političko nad pravnim.

$\mathrm{Na}$ području građanskog prava jedino se u stvarnom pravu suština problema manifestuje neposredno kroz stvar. Ako se pak ta suština prelama kroz odnos između ljudi, tada se institut stvari potiskuje sve dok ne postane imovina a vlasništvo se istanjuje sve dok se ne svede na potraživanje. ${ }^{36}$ Tako stvarno pravo prelazi u obligaciono.

koja muču spadaju volovi, a u nêma spadaju kola", piše Marko Terencije Varon u De re rustica (citirano prema: Danilović, J. - Stanojević, O.: Tekstovi iz rimskog prava, Službeni list SFRJ, Beograd, 1987, str. 14).

$36 \mathrm{Na}$ području ekonomije se ovome analogni proces sastoji u odstranjivanju upotrebne vrednosti robe i njenom svođenju na prometnu vrednost, što u svojoj poslednjoj čistoti dovodi do instituta novca. Tako se u istoj logičkoj ravni sreću u oblasti ekonomije novac a u oblasti prava potraživanje i imovina. U institutu novca se ono apstraktno dovodi do takvog stepena očiglednosti egzistencije da se tu apstrakcija koja je novac doslovno može uzeti u ruke, odneti je daleko od prirodne stvari i tu apstrakciju fizički pokazivati slušaocima predavanja iz filozofije ekonomije i prava. 
Obligacionom pravu je u istoriji filozofije, kao i pravne teorije, često pridavan naročit značaj posredstvom tzv. teorije društvenog ugovora. Po teoriji društvenog ugovora saglasnost volja (istorijska, pretpostavljena ${ }^{37}$ ili fiktivna ${ }^{38}$ ) je način zasnivanja pravnog fenomena. Tako se obligaciono pravo našlo u temelju celokupnog pravnog fenomena. ${ }^{39}$ Ako se stvari pristupi ovako, čini mi se da odmah biva jasno da je u najmanju ruku neobično da se jedna posebna sfera fenomena prava učini temeljem njegovog totaliteta. Ako se dakle saglasnost volja odmah na početku promišljanja ispravno prepozna kao ono što pripada obligacionom pravu, dakle kao ono što je jedna posebna sfera fenomena prava, tada se prosto nameće misao da teorija društvenog ugovora ne odgovara pravom stanju stvari. Nijedno posebno područje pravnog fenomena - obligaciono, stvarno, krivično, upravno, pa čak ni ustavno ${ }^{40}$ - nije temelj celokupnog fenomena prava. ${ }^{41}$

Ako se pravo shvati kao institut slobode, ako se nadalje supstrat prava ispravno shvati kao duh a ne kao psiha, tada nije voljni (psihički) nego duhovni svet ono na čemu se kao svom temelju izgrađuje pravni fenomen. To znači da se svi pravni instituti, uključujući i institute obligacionog prava, najpre izgrađuju kao čisto duhovni fenomeni čije se zakonitosti prostiru metafizičkom sferom. Ti duhovni instituti tek nakon toga stupaju u empirijsku egzistenciju u liku pozitivnog prava i tek nakon svega toga se vezuju za pojedinačna lica i pojedinačne stvari. Vidljivo je da se tek u ovoj fazi razvoja pravnog fenomena pravo sreće sa voljom. Sasvim

37 Društveni ugovor kod Rusoa.

38 Contractus orginarius kod Kanta.

39 ,Temelj svakog prava svojine treba staviti u pravo da se svi isključe iz izvesne slobodne delatnosti koja je rezervisana jedino za nas, a nipošto u isključivo posedovanje objekata. [...] Tako opisano pravo svojine ima svoj pravni osnov, svoju pravno obavezujuću snagu, jedino u ugovoru svih sa svima [...]". (Fihte, J. G.: Zatvorena trgovačka država, Nolit, Beograd, 1979, str. 61). U vezi Fihteovog Zasnivanja pravnog fenomena ne treba izgubiti iz vida ni sledeće stavove: „Fihte je iz načela moralne autonomije izveo pravnu i političku autonomiju čoveka. [...] Primenjen na pitanje o poreklu obaveznosti pozitivnih zakona, princip apsolutne slobode volje značio je da je za pojedinca pozitivni zakon obavezan samo onda kad ga on prihvati svojom voljom, kad ga samom sebi dâ." (Basta, D.: Fihte i Francuska revolucija, SSO Srbije, Beograd, 1981, str. 117).

40 Pri tome ustavnom pravu ostaje neosporen „empirijski prioritet” koji se sastoji u tome što je ustavno pravo prvo empirijsko područje pravnog fenomena. Međutim, ovde nije reč o empirijskom prioritetu jednog područja pozitivnog prava, nego o ontološkom poreklu samog fenomena prava - ovde uopšte nije reč o sferi empirije, nego isključivo o sferi metafizike. O prirodi i položaju ustavnog prava detaljno sam pisao u članku Ontološko određenje ustava, Glasnik AKV, Novi Sad, br. 2-3/2005, str. 59-86.

41 Pišući o Rusoovom Društvenom ugovoru, Hegel mu odaje priznanje da je ,[...] mišljenje sâmo, naime volju postavio kao princip države. No time što je on volju shvaćao samo u određenom obliku pojedinačne volje (kao kasnije Fihte), a opću volju ne kao ono po sebi i za sebe umno volje, nego samo kao ono zajedničko [...] zato ujedinjenje pojedinaca u državi postaje ugovorom [...]". (Hegel, G. W. F.: Osnovne crte filozofije prava, Veselin Masleša - Svjetlost, Sarajevo, 1989, str. 372, § 258). Treba međutim ukazati i na to, da Hegel ovde, kao i na svakom drugom mestu gde kritikuje Rusoov Društveni ugovor, zapravo ne prevazilazi ono što bih hteo da označim „kao Rusoovo stanovište volje” (kao nešto što je suštinski različito od jedino ispravnog ,stanovišta duha”). 
precizno rečeno: pravo se sa voljom sreće tek na području empirije. To znači da se pravni fenomen sa voljom sreće tek u onoj fazi svog formiranja kada je ontološka tajna njegovog nastanka već rešena i postavljena u njegovu ontološku prošlost. Ontološka tajna prava prostire se područjem metafizike a sa voljom se pravni fenomen sreće tek sa zakoračivanjem u područje empirije. To nadalje znači da volja nije ono što čini njegovu ontološku suštinu, nego tek ono što je vezano za jedan aspekt njegove empirijske egzistencije. Ako se dakle problem posmatra sa stanovišta obligacionog prava, možemo reći da volja nije početak nego završetak razvoja sfere obligacionog prava. Ovo zbog toga što je samo po sebi jasno da i svi instituti obligacionog prava - kao i svi instituti celokupnog pravnog fenomena - svoje ontološko poreklo imaju na metafizičkom području. Time se slobodi volje u obligacionom pravu ne želi umanjiti značaj, nego samo jasno odrediti položaj sa jednog suštinskog a to ovde znači ontološkog aspekta.

U svakom slučaju, zakoračivanjem u sferu obligacionog prava u određenom smislu napuštamo institut stvari koji je u obligacionom pravu prisutan tek kao čista apstrakcija iz koje je prirodnost stvari u potpunosti odstranjena, iako u svom prirodnom integritetu negde očuvana ali već izvan tog prava koje je obligaciono. Ako se integritet stvari povrh toga naruši i u jednom neposredno prirodnom smislu - to i dalje podrazumeva ostajanje na području obligacionog prava, ali je u tom slučaju već reč o pravnom institutu štete. Dakle, ako se iz stvari odstrani prirodnost uz njeno puno očuvanje negde izvan ovoga prava koje je obligaciono, tada je reč naprosto o obligacionom pravu. Ako se pak izazove i prirodna negacija prirodnog integriteta stvari kao prirode, tada je takođe reč o obligacionom pravu, ali sada u institutu štete. Ako se šteta nadoknadi, odnosno ako se potraživanje ispuni, tada se iz sfere obligacionog ponovno vraćamo u sferu stvarnog prava - odnosno tada se iz kategorije štete odnosno potraživanja vraćamo kategoriji stvari odnosno vlasništva. U tom smislu treba prihvatiti Radbruhovo stanovište da „obligaciono pravo nosi u sebi klicu svoje smrti: ono se gasi kad sa ispunjenjem postigne svoj cilj". ${ }^{42}$ Po ovoj svojoj karakteristici obligaciono pravo se približava prirodi procesnog prava.

Osvrnimo se ovde i na to da se na ovom nivou razmatranja problem nematerijalne štete suštinski ne razlikuje od problema materijalne štete. Naime, nematerijalna šteta nastaje povredom integriteta tela, psihe ili duha, dakle takođe sfere koja je u pravnom smislu izvan područja apstrakcije. Na taj način se u obligacionom pravu kroz institut nematerijalne štete srećemo sa jednim paradoksom u pogledu pozicije čoveka u pravu: dok se u autentičnom stvarnom pravu čovek nikada ne može pojaviti kao stvar (res cogitans!), dotle se u obligacionom pravu upravo to u izvesnom smislu dešava. U celokupnom pravnom fenomenu, u svim njegovim granama, izuzev obligacionog prava, kada se pravo vezuje za čoveka kao

42 Radbruh, G.: Filozofija prava, Nolit, Beograd, 1980, str. 182. 
prirodno biće uvek dospevamo da pravnog instituta lica a nikada do pravnog instituta stvari. Obligaciono pravo je u tom pogledu izuzetak, iako samo u jednom sasvim određenom i preciznom smislu. Kao što je rečeno, obligaciono pravo uvek podrazumeva odsustvo stvari u njenoj prirodnoj odredbi - stvar je, iako i ovde - samim tim što je reč o građanskom pravu - neosporno relevantna, uvek u svojoj prirodnoj odredbi izvan samih pravnih instituta obligacionog prava. To što je stvar u svojoj prirodnoj odredbi ovde nepobitno relevantna, svrstava obligaciono pravo u građansko pravo, a to što je ta stvar kao prirodna uvek i neizbežno u svom prirodnom liku odstranjena jeste osnovna specifična karakteristika ovog građanskog prava koje time jeste obligaciono. Kada se $\mathrm{u}$ institutu nematerijalne štete ljudsko telo, psiha i duh, kao ono što je prirodno, pojavljuju kao reference, tada oni iz vizure obligacionog prava zapravo imaju prirodu stvari. To je smisao u kome je obligaciono pravo jedina grana prava u kojoj se čovek može pojaviti kao stvar a da pri tome pravo ostane autentično, a to znači - naglašavam - da pri tome pravo ostaje institut slobode. Ovo je moguće zbog toga što je obligaciono pravo u ovde već iznetom smislu zapravo uvek izvan stvari, što se stvar ovde uvek javlja kao ne-stvar, tek kao referenca prava, kao potraživanje. Upravo zahvaljujući tome što je obligaciono pravo iz svoje sfere proteralo svaku stvar kao stvar, što je proteralo njen prirodni lik, ono ima mogućnost da sa te svoje izvan-stvarne distance kao stvar vidi i tretira i ono što izvesno po sebi nije stvar, naime čoveka.

$\mathrm{Za}$ razliku od stvarnog prava unutar koga se sloboda uvek određuje kao ono što se prostire unutrašnjom stranom stvari, obligaciono pravo područje raspona slobode nalazi uvek izvan stvari. U tom smislu možemo reći da je obligaciono pravo naprosto slobodno od svake stvari. Za stvarno pravo bismo ilustrativno mogli reći da neizlečivo pati od fetišizma stvari, dok je obligaciono pravo od toga imuno upravo u jednom apsolutnom smislu.

Obligaciono pravo je jedino područje (grana) prava koje u prirodnoj odredbi kao svoj oslonac nalazi psihičku komponentu, naime komponentu volje. Sloboda volje je ovde prirodno područje prostiranja prava kao duha. Tu slobodu volje, kao ono što je u odredbi psihe, potrebno je jasno razlikovati od slobode kao prava (ovde obligacionog) koje je u odredbi duha - jednako kao što je neizbežno prirodnu odredbu stvari jasno razlikovati od prava raspolaganja kao duhovnog područja prava određenog kao sloboda.

Osvrnimo se na kraju na još jedan pravni institut koji je isključivo vezan za stvar - to je sukcesija.

Sukcesija u jednom suštinskom, ontološkom smislu nikada ne može biti vezana za lica. Doduše, pozitivno-pravni rečnik ne poznaje sukcesiju stvari, nego samo sukcesiju lica - fizičkih i pravnih. Međutim, ono što u svakoj sukcesiji uistinu ostaje neizmenjeno nisu lica nego stvari. Stoga 
možemo reći da sukcesija nije institut lica nego institut stvari. U sukcesiji „stvar menja (niže) lica" jer se jedna ista stvar aktom sukcesije vezuje za nova lica kao sledbenike. Sukcesija je dakle promena pravne vezanosti lica i stvari posmatrana sa stanovišta stvari. Ako se promena pravne vezanosti lica i stvari posmatra sa stanovišta lica, to nije sukcesija nego tek puko raspolaganje pravima na stvari. Pri tome se ni najmanje ne dovodi u pitanje jedan od osnovnih ontoloških principa samog fenomena prava da je svako pravo uvek pravo čoveka, te dakle samim tim uvek vezano za lice, ali o tome ovde naprosto nije reč. ${ }^{43}$

Sukcesija o kojoj je ovde reč vezana je za prestanak egzistencije lica - fizičkih i pravnih. Prestanak egzistencije stvari nikada ne izaziva sukcesiju, nego uvek tek prestanak mogućnosti tzv. stvarnih prava - prelaz iz oblasti stvarnog u druga područja prava (pre svega u obligaciono pravo). Kod prestanka fizičkog lica prelazi se na područje naslednog prava. U tom smislu treba reći da je sukcesija jedan od instituta stvari za koji na strani lica ne postoji pandan. To je razlog što sukcesiju izučava građansko pravo, odnosno što je sukcesija jedan od pod-instituta stvari kao osnovnog instituta građanskog prava. ${ }^{44}$

Tokom istorije prava nije doduše uvek bilo tako. Nasleđivanje plemićkog statusa i zvanja u srednjem veku je sukcesija kao institut lica (za razliku od sukcesije kao instituta stvari): ovde je dakle reč o promeni lica posmatranoj sa stanovišta lica (a ne sa stanovišta stvari kao u građanskom pravu). Isto to, samo „na najvišem nivou plemenitosti” pojavljuje se i u institutu monarha, gde se takođe nasleđuje status i zvanje. Dakle u celokupnom regalnom pravu je reč o promeni lica posmatranoj sa stanovišta lica. Međutim, instituti regalnog prava ne dovode u pitanje opravdanost ovde iznete teze da je pravna sukcesija uvek vezana za lica a nikada za stvari. Ovo zbog toga, što se kod nasleđivanja statusa i zvanja plemića i monarha u jednom suštinskom smislu ne radi o sukcesiji prava nego o sledbeništvu privilegije. Dakle, suština je u tome što ni plemić ni monarh nisu instituti autentičnog prava a to u stvari znači da uopšte nije reč o pravu nego samo o liku prava, samo o prividu prava. ${ }^{45}$ Kada se dakle iz fenomena prava odstrane sve njegove neautentične kategorije, kada se uspostavi jasna i određena razlika između prava i privida prava - videćemo da se sukcesija nikada ne može vezati za lice.

Ontološko poreklo suštinske razlike prava lica i prava stvari treba naravno tražiti u prirodi samog čoveka, tj. u njegovoj ekskluzivnoj spo-

43 U pravnoj teoriji uobičajeno je upravo suprotno stanovište - vidi npr. kod Humbolta: „Svekoliko pravo može se neposredno odnositi uvek samo na ličnost; a na stvari samo ukoliko su te stvari radnjama povezane s ličnošću. Sa prestankom ličnosti, otuda, otpada i to pravo". (Humbolt, V. S.: Ideje za pokušaj odredivanja granica delotvornosti države, Izdavačka knjižarnica Zorana Stojanovića, Novi Sad, 1991, str. 122).

44 Kod sukcesije države u suštini je reč o istom onotološkom zakonu jer je i tamo ono što ostaje stvar a ono što prestaje lice (država kao pravno lice). Dakle, i tamo je sukcesija institut stvari.

$45 \mathrm{U}$ vezi pitanja da li je ustanova monarha institut prava upućujem na svoj članak Ontološko određenje ustava - videti Glasnik AKV, Novi Sad, br. 2-3/2005, str. 76-78. 
sobnosti duhovne produkcije koja ga u svetu prava izdvaja u lice. ${ }^{46} \mathrm{Na}$ tome se ujedno temelji i mogućnost sukcesije u pravnim granama vezanim za stvar, odnosno isključivanje te mogućnosti u pravnim granama vezanim za lice. U aktu duhovne produkcije, unutar koje razaznajemo i produkciju prava kao duha, čovek vrši ospoljavanje duhovnosti i njeno vezivanje za stvari izvan čoveka. Na taj način se iz sfere subjektivnog prelazi u sferu objektivnog duha. Celokupno tzv. pozitivno pravo je fenomen objektivnog duha utoliko što je po aktu svoje egzistencije vezano za stvarnost izvan čoveka kao subjekta. ${ }^{47}$ Kada kažemo da život jednog čoveka nadilazi njegovo delo, zapravo smo rekli da su objektivne duhovne tvorevine ono što ostaje i nakon smrti čoveka kao pojedinca. Kao što je upravo naznačeno, objektivitet te duhovnosti sastoji se u njenoj stvarnosti, ${ }^{48}$ u njenoj vezanosti za stvari. Kada dakle govorimo o sukcesiji kao institutu stvari, polazimo od činjenice da pozitivno pravo sa stanovišta svoje egzistencije nije fenomen subjektivnog nego objektivnog duha što znači da se ono u aktu svoje egzistencije vezuje za stvari a ne za lica, iako uvek važi u odnosu na lica a nikada u odnosu na stvari (kao i svako pravo).

Subjekti mogu stupati u sukcesiju upravo zahvaljujući tome što su duhovna bića, što dakle raspolažu sposobnošću duhovne produkcije ovde značajne kao duhovne objektivizacije. Subjekti imaju sposobnost vezivanja duhovnosti za stvari i upravo je to momenat koji omogućava sukcesiju i u čemu se ona u krajnjem ontološkom smislu i sastoji. U svetu stvari ne postoji ništa slično: čak ni najinteligentnije životinje (koje u pravnom smislu takođe - i upravo zbog toga - spadaju u stvari) ne poseduju duhovni sloj, te je svaka mogućnost duhovne produkcije a time i objektivizacije samim tim isključena. Zbog toga nikada ne možemo govoriti o sukcesiji stvari. A ipak je sukcesija institut stvari - u ovde rečenom smislu.

„Nasledno pravo nije ništa drugo do stupanje u sva prava koja je imao pokojnik". ${ }^{49} \mathrm{Sa}$ stanovišta onoga što je ovde izneto, isto to bi se moglo reći i ovako: nasledno pravo nije ništa drugo do stupanje lica u stvari, promena lica uspostavljena sa stanovišta stvari. ${ }^{50} \mathrm{U}$ ovom smislu,

46 O tome sam detaljno pisao u članku Konstituisanje lica - videti Glasnik AKV, Novi Sad, br. 11/2004, str. $437-453$.

47 Ovde je potrebno jasno razlikovati egzistenciju prava od njegovog važenja. Pravo najpre postoji $\mathrm{i}$ tek na tome se zasniva mogućnost njegovog važenja. Egzistencija prava je njegov odnos prema biću, važenje je njegov odnos prema pravnom poretku.

48 U nemačkom jeziku postoji terminološka i pojmovna razlika koja ovde može biti korisna za razjašnjenje pojma stvarnosti u značenju koji ona ima u ovom kontekstu - reč je o terminima odnosno pojmovima Sachlichkeit (stvarnost) i Wirklichkeit (zbiljnost).

49 ,Hereditas nihil aliud est, quam successio in universum ius quod defunctus habuerit." (D. 50. 17. 62 - izvor i prevod prema: Danilović, J. - Stanojević, D.: Tekstovi iz rimskog prava, Službeni list SFRJ, Beograd, 1987, str. 187).

50 Nešto slično, iako ipak bitno različito, tvrdi i Kant kada piše o ostavljanju dobrog glasa posle smrti: „Da bi pokojnik posle svoje smrti (kad ga, dakle, više nema) mogao još nešto posedovati, bilo bi besmisleno zamišljati kad bi ostavština bila neka stvar. Ali dobar glas je prirođeno, spoljašnje, mada samo idealno Moje ili Tvoje, što pripada subjektu kao 
pomalo metaforično možemo reći da kao što institut stvari započinje u licu, tako institut lica završava u stvari. Setimo se na kraju Hobsove misli: „Ta veštačka večitost je ono što ljudi nazivaju pravom nasleđa". ${ }^{51}$

\section{ESTABLISHMENT OF THINGS}

Janko Kubinjec, PhD

\section{Sum mary}

Legal concept of person is to be constituted, while the legal concept of thing is to be established. Legal concept of thing is a metaphysical category that shall be differentiated from the positive-legal definition of thing as an empirical phenomenon, as well from the natural thing, which is also as an empirical phenomenon. Legal concept of thing is a spiritual phenomenon, which belongs to the field of objective spirit. The thing is the basis for the entire civil law. The wrong conclusion that civil law starts with ownership and ownership with possession, is based on the so called naturalistic error. For the title, the thing is primarily a freedom for the person, while the mortgage is the border with which the owner is confronted. At the point where freedom overflows from person to thing we have erga omnes effect of property rights. It is not possible to clearly and materially differentiate person from the thing without defining the law as the freedom, and without making this distinction, the persons can also be defined as res cogitans. In the property law, the essence is manifested through the human relationship. In the law of the contracts and torts the thing is neglected up to the point where we come to property, and point where property becomes the claim. If, in addition to that, directly natural refutation of things is produced, we are faced with the legal concept of damages. In the authentic law, the succession is always the concept pertaining to things and only in the non authentic law it may be the concept pertaining to persons.

Keywords: Thing, metaphysical phenomenon, empirical phenomenon, spirit, naturalistic error, ownership, mortgage, property, claim, damages, succession

osobi [...]" (Kant, I.: Metafizika morala, Izdavačka knjižarnica Zorana Stojanovića, Sremski Karlovci, 1993, str. 96, §35).

51 Hobs, T.: Levijatan, I, Gradina, Niš, 1991, str. 199. 